\title{
Evaluation of acute toxicity of the "Orgasept" disinfectant
}

\author{
V.L. Kovalenko ${ }^{*}$, G.V. Ponomarenko ${ }^{*}$, M.D. Kukhtyn ${ }^{3}$, A.P. Paliy ${ }^{4,}$, , O.O. Bodnar ${ }^{5}$, \\ H.I. Rebenko', T.G. Kozytska7, T.V. Makarevich ${ }^{8}$, O.V. Ponomarenko², A.P. Palii ${ }^{9}$ \\ ${ }^{1}$ State Scientific Control Institute of Biotechnology and strains microorganisms, \\ 30 Donetska St, Kyiv, 03151, Ukraine \\ ${ }^{2}$ Kharkiv State Zooveterinary Academy, 1 Akademicheskaya St, urban settlement Malaya Danilivka, \\ Dergachivsky district, Kharkov region, 62341, Ukraine \\ ${ }^{3}$ Ternopil Ivan Puluj National Technical University, 56 Ruska St, Ternopil, 46000, Ukraine \\ ${ }^{4}$ National Scientific Center "Institute of Experimental and Clinical Veterinary Medicine", \\ 83 Pushkinska St, Kharkiv, 61023, Ukraine \\ ${ }^{5}$ State Agrarian and Engineering University in Podilia, 13 Schevchenko St, Kamianets-Podilskyi, Khmelnytskyi \\ region, 32300, Ukraine \\ ${ }^{6}$ Sumy National Agrarian University, 160 G. Kondratieva St, Sumy, 40021, Ukraine \\ ${ }^{7}$ State Scientific and Research Institute of Laboratory Diagnostics and Veterinary and Sanitary Expertise, 30 \\ Donetska St, Kyiv, 03151, Ukraine \\ ${ }^{8}$ Odessa State Agrarian University, 13 Panteleimonovskaya St, Odessa, 65012, Ukraine \\ ${ }^{9}$ Kharkiv National Technical University of Agriculture named after Petro Vasylenko, \\ 44 Alchevskih St, Kharkiv, 61002, Ukraine \\ Corresponding author e-mails: kovalenkodoktor@gmail.com ${ }^{1}$,gpkh1966@gmail.com²
}

Received: 21.08.2020. Accepted: 30.09.2020

\begin{abstract}
The purpose of the research was to study acute toxicity, irritating and sensitizing effects, biochemical and immunological parameters of animal blood after influence of "Orgasept" disinfectant, consisted from silver nanoparticles, benzalkonium chloride and lactic acid. To determine acute toxicity, 6 months old clinically healthy male rats ( 5 groups, six rats per each group) and female rats ( 5 groups, six per each group) with body weight of $180-200 \mathrm{~g}$ were used. We determined the average lethal dose $\left(\mathrm{LD}_{50}\right)$ and the main parameters of acute toxicity after Orgasept rats administration in various dozes. We found that, at intra-gastrointestinal administration of Orgasept, the $L_{50}$ for male rats was $5000.0 \pm 43.0 \mathrm{mg} / \mathrm{kg}$ body weight and $5045.0 \pm 56.3 \mathrm{mg} / \mathrm{kg}$ for the females. We also registered that Orgasept does not have cumulative and sensitizing properties, does not show irritating effect, suppressive effect on growth and development of animals, and does not affect the hemopoiesis. We revealed that Orgasept demonstrated significant effect on nonspecific and specific factors of the organism's protection compared to the formaldehyde.

Key words: disinfectant, Orgasept, acute toxicity, laboratory rats, irritating and sensitizing properties.
\end{abstract}

\section{Introduction}

Disinfection is a leading factor in ensuring the epizootic welfare of livestock and obtaining safe products of animal origin of high sanitary quality (Zavgorodniy et al., 2013; Gosling, 2018). Disinfection technologies are especially important in the prevention and control of vaccine-uncontrolled diseases (Paliy et al., 2015; De Lorenzi et al., 2020), and due to the concentration of a significant number of animals in limited areas when transferred livestock on an industrial scale (Stringfellow et al., 2009; Shkromada et al., 2019).

Recently, disinfection approach has changed due to latest biocidal products (Paliy et al., 2016; Kovalenko et al., 2018; Stegniy et al., 2019). This is confirmed the emergence of resistant microorganisms to the action of antimicrobial drugs (Huang et al., 2006; Hadzevych et al., 2019), including disinfectants (Kamal, et al., 2019) with a modern understanding of the environmental aspects of the use of antibacterial drugs (Roeder et al., 2010; Jones et al., 2018). The generally accepted classical concept of disinfection, as the destruction or removal of the infective matter, became the basis for the fact that disinfection is understood only as a specific technique of decontamination. But such a definition and understanding of the purpose and objectives of disinfection does not cover modern ideas about its role as an independent scientific discipline and its goals and objectives in the overall set of measures to influence the infectious process (Gebel et al., 2013; Horiuk et al., 2019; Paliy et al., 2020b).

Factors, influenced the transmission of pathogens are soil, animal housing, manure, care tools, transportation, water bodies, animal products, and animal carcasses (Leggett et al., 2017; Paliy et al., 2018b; 2019b). There are potential microbial risks associated with the air in livestock facilities (Abd-Elallet al., 2009) as well as parasitic insects (Paliy et al., 2018a). In the external environment, many adverse conditions affect the pathogens and cause the death of microorganisms (Haruta \& Kanno, 2015). However, all of these factors do not replace or preclude the use of disinfectants to completely disinfect contaminated objects (Paliy et al., 2018c; Palii et al., 2020; Takagi \& Yagishita, 2020; Costard et al., 2009).

High efficiency combined with simplicity and economy of operation promotes wide use of disinfection in animal husbandry and veterinary. Among them, number of disinfectants of various origins and biocidal properties are used in Ukraine. Among the means of physical origin, the most relevant is ultraviolet radiation (Zavgorodniy et al., 2019; Rodionova et al., 2020). The most common 
chemicals today are based on glutaraldehyde (Orsi et al., 2010; Paliy et al., 2020c), chlorine-active compounds (Paliy, 2014; Kamal et al., 2019; Paliy et al., 2019a), oxidants (Lineback et al., 2018; Paliy, 2018) and other compounds (Rutala, 1996; Rabenau et al., 2005). Disinfectants are proposed for use in low ambient temperatures (Paliy et al., 2020a). Most existing agents are relatively inexpensive, have a broad spectrum of bactericidal action, but are toxic, can be carcinogenic and have high corrosive activity (Curran et al., 2019; Jin et al., 2020). Currently, the use of bactericidal substances - lactic acid and quaternary ammonium compounds (QACs) in the composition of disinfectants is in great demand. They are well soluble in water, colorless, almost odorless, have high bactericidal and surface activity, combined with low toxicity and no irritating and other side effects (Souza et al., 2015; Addie et al., 2015; Ponomarenko et al., 2017a). They do not form toxic products, are not inactivated by proteins, stable, nonaggressive.

Over the last decade, the use of silver nanoparticles as the main active ingredient in many modern disinfectants has become more widespread (Susan et al., 2009; De Gusseme et al., 2010; Ivask et al., 2014; Lopes et al., 2016). The basis of the antibacterial action of silver is its partial oxidation and release of silver ions, which when interacting with thiol groups of peptidoglycans of the bacterial cell wall and cell membrane proteins, cause cell lysis. Silver ions can also bind to bacterial DNA, preventing its replication and stopping the synthesis of bacterial proteins (Likus et al., 2013). At the nanoscale, silver exhibits extraordinary physical, chemical and biological properties. Due to the pronounced antibacterial activity, nanosilver is used not only for disinfection of liquids, equipment or premises, but also for the treatment of wounds and burns. Thus, the use of nanosilver is becoming increasingly common in human and veterinary medicine, as well as in related fields (Chen, \& Schluesener, 2008; Benn et al., 2010). Therefore, the bactericidal agents with high biological activity, low toxicity, and bactericidal, antiviral and antifungal action can be proposed as an alternative to traditional disinfectants and antibacterial agents (Ponomarenko et al., 2017b).

The aim of our research was to study the acute toxicity, irritating and sensitizing effects, biochemical and immunological parameters of animal blood under the action of bactericidal disinfectant Orgasept consisted of silver nanoparticle, benzalkonium chloride and lactic acid.

\section{Materials and methods}

To determine the disinfectant acute toxicity, 6-months clinically healthy male rats (5 groups, six in each group, $\mathrm{n}=30$ ) and female rats (5 groups, six in each group, $\mathrm{n}=30$ ) with body weight of $180-200 \mathrm{~g}$ were used. Laboratory research was carried out in the Educational and Scientific Laboratory for Molecular Genetic Research Methods named after P.I. Verbitskiy at the Department of Epizootology and Veterinary Management of the Kharkiv State Zoo Veterinary Academy. Depending on the amount of Orgasept administered to rats, the average lethal dose $\left(L_{50}\right)$ and the main parameters of acute toxicity were determined using Kerber's method (Kotsiumbas et al., 2006). Classification of substances by toxicity was carried out according to the table of toxicity levels GOST 12.1.007-76. Determination of the irritant action to control the development of contact non-allergic dermatitis was carried out by daily application of the solution on the skin of rat's back for 30 days. In experimental groups ( 5 rats in each), the recommended concentrations of Orgasept $(0.3 \%$ and $0.5 \%)$ and the non-diluted Orgasept concentrate were used. In control group ( $n=5)$, a physiological solution was used. Sensitizing properties of Orgasept were studied in one group with 10 rats. A single application of $0.3 \%$ Orgasept solution was administered daily to the right rat side, after shaving of the coat, dirung 20 days. The skin from rats' left side was a control, where we made one-time application of $0.9 \%$ saline solution (Kovalenko \& Nedosekov, 2011).

The compilation and recording of opsonophagocytic reaction with the study of phagocytic activity, phagocytic index and absolute complete phagocytosis of rat blood were performed according to V. V. Chumachenko modified method (Buchko, 2015). The modern human methods of laboratory animals care were used (Buckmaster, 2012). Data in the tables were presented like means and standard deviations

\section{Results and discussion}

When applied Orgasept to the rats, we did not see any change in the behavior of animals, or in any functional features. In addition, the absence of harmful effects of the drug Orgasept was evidenced by the results of the pathological and anatomical section of the animals slaughtered at the end of the experiment. The results of pathoanatomical studies did not show any cumulative properties of the disinfectant Orgasept.

According to the results of studies of irritating action, it was found that when using the working concentrations of the drug Orgasept there was no irritation of the skin or any other organs and tissues, indicating no negative effect of the drug on living organisms. We found that only in the first minutes after application of the solution the animals attempted to lick the wetted area of the skin, then calmed down and the behavior remained adequate. The surface of the treated with disinfectant area of the skin had a weak hyperemia for two hours. After washing the disinfectant with water, skin damage, edema, and hyperemia were not detected. Therefore, the analysis of the results of studies has helped to find out that the working concentrations of the drug Orgasept do not cause irritating and sensitizing effects, the disinfectant has no cumulative properties.

Initial results presented in Table 1 . Further analysis revealed that after intragastric administration of the drug "Orgaspet" the $\mathrm{LD}_{50}$ for male rats was $5000.0 \pm 43.0 \mathrm{mg} / \mathrm{kg}$ body weight, and for male rats $-5045.0 \pm 56.3 \mathrm{mg} / \mathrm{kg}$.

Table 1. Acute toxicity of Orgasept in rats under the intragastric administration $(n=6)$

\begin{tabular}{|c|c|c|c|c|c|}
\hline \multirow{2}{*}{ Characteristics } & \multicolumn{5}{|c|}{ Dose of the preparation, $\mathrm{mg} / \mathrm{kg}$} \\
\hline & 4800 & 4900 & 5000 & 5100 & 5200 \\
\hline & \multicolumn{5}{|c|}{ Males } \\
\hline Number of animals, heads & 6 & 6 & 6 & 6 & 6 \\
\hline survived, heads & 6 & 5 & 4 & 2 & 0 \\
\hline \multirow[t]{3}{*}{ died, heads } & 0 & 1 & 2 & 4 & 6 \\
\hline & & & & $\mathrm{LD}_{50}=$ & \pm 43.0 \\
\hline & \multicolumn{5}{|c|}{ Females } \\
\hline Number of animals, heads & 6 & 6 & 6 & 6 & 6 \\
\hline survived, heads & 6 & 4 & 4 & 1 & 0 \\
\hline died, heads & 0 & 2 & 2 & 5 & 6 \\
\hline
\end{tabular}


Changes in the non-specific resistance of animals under the action of the drug Orgasept were studied in the directions of comparative study of the influence of disinfectants of formaldehyde and Orgasept on nonspecific and specific factors of protection of the organism depending on the concentration and exposure of their application. During the research of the facilities where laboratory animals were kept, they were treated with preparations of formaldehyde and Orgasept. We considered that non-specific resistance of the organism regards activity and intensity of phagocytosis, namely the parameters of opsonophagocytic response were the characteristic features (Table 2).

Table 2. Influence of disinfectants on the immune status of rats $(n=6)$

Period of investigation, days

1

15

30

1

15

30

1

15

30

$* p \leq 0.05$ to control.

$\begin{array}{cc}12.0 \pm 0.32 * & 9.2 \pm 0.39 * \\ 11.7 \pm 0.33 & 11.5 \pm 0.54 \\ 12.1 \pm 0.44 & 11.9 \pm 0.33\end{array}$

0.5

Orgasept doze, \% 1.5

$3.8 \pm 0.56$
$4.2 \pm 0.74$
$4.2 \pm 0.19$

$4.1 \pm 0.58$

$4.4 \pm 0.75$

\section{Groups of experimental animals}

3.0

Phagocytic activity, \%

Formaldehyde doze, \% $1.5 \quad 3.0$

Control

$\begin{array}{lcccc}9.9 \pm 0.85 * & 11.0 \pm 0.60 * & 9.8 \pm 0.70 * & 9.5 \pm 1.10 * & 12.5 \pm 0.31 \\ 10.2 \pm 0.75 & 11.1 \pm 0.13 & 10.1 \pm 0.56 & 10.1 \pm 0.54 & 12.4 \pm 0.89 \\ 10.6 \pm 0.42 & 11.9 \pm 0.54 & 11.8 \pm 0.62 & 10.0 \pm 0.56 & 12.1 \pm 0.32\end{array}$

Phagocytic index

According to the results of researches of these indicators in laboratory animals under their treatment with 0.5 , 1.5 , and $3.0 \%$ solution of the drug Orgasept it was found that in 5 hours after treatment with the disinfectant, regardless of its concentration, animals showed a probable decrease in phagocytic activity, especially under the action of $3.0 \%$ solution. However, subsequent studies of the activity of neutrophils of peripheral blood in 15 days after treatment of animals indicated its growth in all experimental groups of animals. After 30 days in animals treated with 0.5 and $1.5 \%$ solution of the drug Orgasept, phagocytic activity did not differ from those in animals in the control group. In the experimental group of animals treated with $3.0 \%$ solution of the Orgasept, the phagocyte activity values remained lower than those in control animals at $0.7 \%$, which showed a somewhat suppressive effect of disinfectant in such a concentration on the body of rats. In this case, the phagocytic index in animals, under the treatment of facilities with a $0.5 \%$ solution of disinfectant, did not change, and after 15 and 30 days, even had a slight tendency for unreliable growth in the range from 0.5 to $1.2 \%$. In the group of laboratory animals, which were treated with higher concentrations of the drug -1.5 and $3.0 \%$, in 15 days after treatment, the characteristics of the phagocytic index were unlikely to increase.

We saw that 30 days after the application of $1.5 \%$ solution of Orgasept in the experimental animals, the phagocyte index did not differ from that of the animals in the control group. In animals treated with the $3.0 \%$ solution of the drug, the characteristics of the phagocytic index remained below the control by 3.5\%, which showed a slight suppressive effect of this concentration of drug on the phagocytic properties of neutrophils of peripheral blood in rats. Therefore, $0.5 \%$ solution of the drug Orgasept was optimal for the treatment of animals, because in 15 days the parameters of opsonophagocytic reaction came to the norm. Our studies showed that $0.5 \%$ concentration of the drug administered orally at a dose of $1 \mathrm{~cm}^{3}$ did not lead to visible pathological and anatomical changes in laboratory animals. The latter was established at the autopsy after their euthanasia and indicated a low toxicity and harmlessness of the drug in case of application in the working concentrations of the drug. The analysis of the results of morphological, biochemical and immunological studies of blood of rats under the processing with $0.5 \%$ solution of disinfectant Orgasept showed that the initial and final indices in animals of the experimental and control groups were within the normal range.

The level of endogenous intoxication of the body of rats (sorption capacity of erythrocytes) of the experimental and control groups during the observation period was stable and amounted to $17.15 \%$ on average, which indicates the absence of suppressor action of the disinfectant Orgasept on the antioxidant properties of the animal's organism. Thus, it has been experimentally confirmed that the drug Orgasept has no suppressive effect on metabolic processes in rats. The use of effective and safe disinfectants is of paramount importance in providing the population with quality products of animal origin (Paliy et al., 2017, 2018d). One of the main criteria that determines the feasibility of using disinfectants in practical conditions is their environmental safety and low toxicity to staff and animals (Du et al., 2017; Bondarchuk et al., 2019).

In the development of intoxication of the macroorganism with potent toxic substances there are four periods: the period of contact; hidden period; period of toxic pulmonary edema; period of complications (Presgrave et al., 2008). Substances with a weak cauterizing effect are dangerous, in particular phosphorus chloride and sulfur chloride. Inhalation of phosphorus chloride vapors for several minutes at a concentration of $0.08-0.15 \mathrm{~g} / \mathrm{m}^{3}$ leads to acute poisoning (Wason et al., 1984). The disinfectants belonging to hazard classes 3 and 4 can be recommended for use in various ways of their entry into the body with no or weak local irritant and sensitizing effects (Catlin et al., 2018). Disinfectants containing glutaraldehyde and quaternary ammonium compounds (Lin et al., 2018) are considered safe. High antibacterial activity of nanoparticles, especially against gram-negative and gram-positive bacteria is regarded as a positive effect, but there is a possibility of potential risk in their use in terms of toxic effects (Bąkowski et al., 2018). Nanoparticles have been shown to be toxic to bacteria, algae and invertebrates (Exbrayat et al., 2015). The results of our research generally coincide with the information given in the works of other authors who studied and analyzed experimental data on the toxic effects of silver nanoparticles on the body not only of laboratory animals but also of humans (Armstrong et al., 2013; Kovalenko et al., 2017; Yousef et al., 2019).

\section{Conclusions}

Ukrainian Journal of Ecology, 10(4), 2020 
We registered that the Orgasept $L_{50}$ for male rats was $5000.0 \pm 43.0 \mathrm{mg} / \mathrm{kg}$ body weight and for female rats $-5045.0 \pm 56.3 \mathrm{mg} / \mathrm{kg}$. After our experiments, we finally proved that Orgasept belongs to class IV in accordance with the classification of dangerous substances. We also revealed that Orgasept does not have cumulative and sensitizing properties and does not demonstrate an irritating effect.

\section{References}

Abd-Elall, A. M., Mohamed, M. E., \& Awadallah, M. A. (2009). Potential airborne microbial hazards for workers on dairy and beef cattle farms in Egypt. Veterinaria Italiana, 45 (2), 275-285.

Addie, D. D., Boucraut-Baralon, C., Egberink, H., Frymus, T., Gruffydd-Jones, T., ... Möstl, K. (2015). Disinfectant choices in veterinary practices, shelters and households: ABCD guidelines on safe and effective disinfection for feline environments. J. Feline Med. Surg., 17 (7), 594-605. doi: $10.1177 / 1098612 X 15588450$

Armstrong, N., Ramamoorthy, M., Lyon, D., Jones, K., \& Duttaroy, A. (2013). Mechanism of silver nanoparticles action on insect pigmentation reveals intervention of copper homeostasis. PLoS One, 8 (1), 53186. doi: 10.1371/journal.pone.0053186

Bąkowski, M., Kiczorowska, B., Samolińska, W., Klebaniuk, R., \& Lipiec, A. (2018). Silver and Zinc Nanoparticles in Animal Nutrition - A Review. Annals of Animal Science, 18 (4), 879-898. doi: 10.2478/aoas-2018-0029

Benn, T., Cavanagh, B., Hristovski, K., Posner, J. D., \& Westerhoff, P. (2010). The release of nanosilver from consumer products used in the home. J Environ Qual., 39 (6), 1875-1882. doi: 10.2134/jeq2009.0363

Bondarchuk, A. O., Paliy, A. P., \& Blazheyevskiy, M. Ye. (2019). Determination of acute toxicity of the Bondarmin disinfectant. Journal for Veterinary Medicine, Biotechnology and Biosafety, 5 (2), 26-30. doi: 10.36016/JVMBBS-2019-5-2-5

Buchko, O. (2015). Free Radical Processes in the Pig's Organism Under the Influence of the Biologically Active Supplements. Lesya Ukrainka Eastern European National University Scientific Bulletin. Series: Biological Sciences, 313 (12), 143-150. doi: 10.29038/2617-4723-2015-313-143-150

Buckmaster, C. (2012). Shifting the culture of lab animal care. Lab. Animal (NY), 41 (7), 205. doi: 10.1038/laban0712-205

Catlin, N. R., Willson, C. J., Creasy, D. M., Rao, D. B., Kissling, G. E., McIntyre, B. S., \& Wyde, M. (2018). Differentiating between Testicular Toxicity and Sexual Immaturity in Ortho -phthalaldehyde Inhalation Toxicity Studies in Rats and Mice. Toxicologic Pathology, 46 (7), $753-763$. doi: $10.1080 / 08958378.2017 .1390015$

Chen, X, \& Schluesener, H. J. (2008). Nanosilver: A nanoproduct in medical application. Toxicol Lett., 176 (1), 1-12. doi: 10.1016/j.toxlet.2007.10.004

Costard, S., Porphyre, V., Messad, S., Rakotondrahanta, S., Vidon, H., Roger, F., \& Pfeiffer, D. U. (2009). Multivariate analysis of management and biosecurity practices in smallholder pig farms in Madagascar. Preventive Veterinary Medicine, 92 (3), $199-209$. doi: 10.1016/j.prevetmed.2009.08.010

Curran, E. T., Wilkinson, M., \& Bradley, T. (2019). Chemical disinfectants: Controversies regarding their use in low risk healthcare environments (part 1). Journal of Infection Prevention, 20 (2), 76-82. doi: 10.1177/1757177419828139

De Gusseme, B., Sintubin, L., Baert, L., Thibo, E., Hennebel, T., ... Boon, N. (2010). Biogenic silver for disinfection of water contaminated with viruses. Appl. Environ. Microbiol., 76 (4), 1082-1087. doi: 10.1128/AEM.02433-09

De Lorenzi, G., Borella, L., Alborali, G. L., Prodanov-Radulović, J., Štukelj, M., \& Bellini, S. (2020). African swine fever: A review of cleaning and disinfection procedures in commercial pig holdings. Research in Veterinary Science. doi: 10.1016/j.rvsc.2020.06.009

Du, Y., Lv, X.-T., Wu, Q.Y., Zhang, D.-Y., Zhou, Y.-T., Peng, L., \& Hu, H.-Y. (2017). Formation and control of disinfection byproducts and toxicity during reclaimed water chlorination: A review. Journal of Environmental Sciences, 58, 51-63. doi. 10.1016/j.jes.2017.01.013

Exbrayat, J.-M., Moudilou, E., \& Lapied, E. (2015). Harmful Effects of Nanoparticles on Animals. Journal of Nanotechnology, 2015 (8), ID 861092. doi: $10.1155 / 2015 / 861092$

Gebel, J., Exner, M., French, G., Chartier, Y., Christiansen, B., ... Sonntag, H. G. (2013). The role of surface disinfection in infection prevention. GMS hygiene and infection control, 81), Doc10. doi: $10.3205 /$ dgkh000210

Gosling, R. J. (2018). A review of cleaning and disinfection studies in farming environments. Livestock, 23 (5), $232-237$.

Hadzevych, O. V., Paliy, A. P., Kinash, O. V., Petrov, R. V., \& Paliy, A. P. (2019). Antibiotic resistance of microorganisms isolated from milk. World of Medicine and Biology, 3 (69), 245-250. doi: 10.26724/2079-8334-2019-3-69-245-250

Haruta, S., \& Kanno, N. (2015). Survivability of Microbes in Natural Environments and Their Ecological Impacts. Microbes Environ, 30 (2), $123-125$. doi: $10.1264 /$ jsme2.ME3002rh

Horiuk, Y., Kukhtyn, M., Kovalenko, V., Kornienko, L., Horiuk, V., \& Liniichuk, N. (2019). Biofilm formation in bovine mastitis pathogens and the effect on them of antimicrobial drugs. Independent Journal of Management \& Production, 10 (7), 897-910. doi: 10.14807/ijmp.v10i7.1012

Huang, S. S., Datta, R., \& Platt, R. (2006). Risk of acquiring antibiotic-resistant bacteria from prior room occupants. Arch Intern Med., 166 (18), 1945-1951. doi: 10.1001/archinte.166.18.1945

Ivask, A., Kurvet, I., Kasemets, K., Blinova, I., Aruoja, V., ... Kahru, A. (2014). Size-dependent toxicity of silver nanoparticles to bacteria, yeast, algae, crustaceans and mammalian cells in vitro. PLoS One, 9 (7), 102-108. doi: 10.1371/journal.pone.0102108

Jin, M., Liu, L., Wang, D., Yang, D., Liu, W., ... Li, J. (2020). Chlorine disinfection promotes the exchange of antibiotic resistance genes across bacterial genera by natural transformation. The ISME Journal, 14, 1847-1856 (2020). doi: 10.1038/s41396-020-0656-9

Jones, C. H., Shilling, E. G., Linden, K. G., \& Cook, S. M. (2018). Life Cycle Environmental Impacts of Disinfection Technologies Used in Small Drinking Water Systems. Environ. Sci. Technol., 52 (5), 2998-3007. doi: 10.1021/acs.est.7b04448

Kamal, M. A., Khalaf, M. A., Ahmed, Z., \& Jakee, J. E. (2019). Evaluation of the efficacy of commonly used disinfectants against isolated chlorineresistant strains from drinking water used in Egyptian cattle farms. Veterinary world, 12 (12), 2025-2035. doi: 10.14202/vetworld.2019.20252035

Kotsiumbas, I. Ya., Malik, O. G., \& Paterega, I. P. (2006). Preclinical studies of veterinary drugs. Lviv. Triada plus (in Ukrainian)

Kovalenko, V. L., Kovalenko, P. L., Ponomarenko, G. V., Kukhtyn, M. D., Midyk, S. V., Horiuk, Yu. V., \& Garkavenko, V. M. (2018). Changes in lipid composition of Escherichia coli and Staphylococcus areus cells under the influence of disinfectants Barez $₫$, Biochlor $₫$ and Geocide $\Re$. Ukrainian Journal of Ecology, 8 (1), 547-550. doi: 10.15421/2018_248

Kovalenko, V. L., \& Nedosekov, V. V. (2011). Methodical approaches to control of disinfectants for veterinary medicine. Kiev. NUBiP Ukraine (in Ukrainian)

Kovalenko, V. L., Ponomarenko, O. V., Korniyenko, V. I., Harkusha, I. V., \& Gordiyenko, A. D. (2017). Antibacterial effect of vegetable essential oils based on metal nanoparticles in vitro. Journal for Veterinary Medicine, Biotechnology and Biosafety, 3 (3), 34-36.

Leggett, H. C., Cornwallis, C. K., Buckling, A., \& West, S. A. (2017). Growth rate, transmission mode and virulence in human pathogens. Philosophical transactions of the Royal Society of London. Series B, Biological sciences, 372 (1719), 20160094. doi: 10.1098/rstb.2016.0094

Likus, W., Bajor, G., \& Siemianowicz, K. (2013). Nanosilver - does it have only one face? Acta Biochim. Pol., 60 (4), 495-501.

Lineback, C. B., Nkemngong, C. A., Wu, S. T., Li, X., Teska, P. J., \& Oliver, H. F. (2018). Hydrogen peroxide and sodium hypochlorite disinfectants are more effective against Staphylococcus aureus and Pseudomonas aeruginosa biofilms than quaternary ammonium compounds. Antimicrob Resist Infect Control, 7, 154 (2018). doi: 10.1186/s13756-018-0447-5 
Lin, W., Niu, B., Yi, J., Deng, Z., Song, J., \& Chen, Q. (2018). Toxicity and Metal Corrosion of Glutaraldehyde-Didecyldimethylammonium Bromide as a Disinfectant Agent. BioMed Research International, 2018, ID 9814209. doi: 10.1155/2018/9814209

Lopes, L. Q., Santos, C. G., de Almeida Vaucher, R., Gende, L., Raffin, R. P., \& Santos, R. C. (2016). Evaluation of antimicrobial activity of glycerol monolaurate nanocapsules against American foulbrood disease agent and toxicity on bees. Microb Pathog., 97, 183-188. doi: 10.1016/j.micpath.2016.05.014

Orsi, I. A., Villabona, C. A., Kameoka, E., Ferreira, M. C. C. G., Ito, I. Y., \& Saraiva, M. E. (2010). Antimicrobial efficacy of chemical disinfectants on contaminated full metal crowns. Brazilian Dental Journal, 21 (3), 241-246. doi: 10.1590/S0103-64402010000300012

Palii, A. P., Paliy, A. P., Rodionova, K. O., Zolotaryova, S. A., Kushch, L. L., ... Umrihina, O. S. (2020). Microbial contamination of cow's milk and operator hygiene. Ukrainian Journal of Ecology, 10 (2), 392-397. doi: 10.15421/2020_113

Paliy, A. (2014). Determination of specific stability Mycobacterium to chlorine containing disinfectant preparation. Bulletin of National Agrarian University of Armenia, 2, 84-86.

Paliy, A. P. (2018). Antibacterial effect of "Ecocide C" disinfectant against mycobacteria. Ukrainian Journal of Ecology, 8 (1), 141-147. doi: 10.15421/2018_198

Paliy, A. P., Ishchenko, K. V., Marchenko, M. V., Paliy, A. P., \& Dubin, R. A. (2018c). Effectiveness of aldehyde disinfectant against the causative agents of tuberculosis in domestic animals and birds. Ukrainian Journal of Ecology, 8 (1), 845-850. doi: 10.15421/2018_283

Paliy, A. P., Rodionova, K. O., Braginec, M. V., Paliy, A. P., \& Nalivayko, L. I. (2018d). Sanitary-hygienic evaluation of meat processing enterprises productions and their sanation. Ukrainian Journal of Ecology, 8 (2), 81-88. doi: 10.15421/2018_313

Paliy, A. P., Rodionova, K. O., \& Paliy, A. P. (2017). Contamination of animals and poultry meat and means of its reduction. Food Science and Technology, 11 (4), 64-71. doi: 10.15673/fst.v11i4.732

Paliy, A. P., Stegniy, B. T., Kuzminov, A. V., Buzun, A. I., Gerilovich, A. P., Bogach, M. V., \& Stegniy, M. Y. (2020c). Effectiveness of aldehyde disinfectant "DZPT-2" against the African swine fever virus. Ukrainian Journal of Ecology, 10 (3), 131-138. doi : 10.15421/2020_146

Paliy, A. P., Stegniy, B. T., Muzyka, D. V., Gerilovych, A. P., \& Korneykov, O. M. (2016). The study of the properties of the novel virucidal disinfectant. Agricultural Science and Practice, 3 (3), 41-47. doi: 10.15407/agrisp3.03.041

Paliy, A. P., Sumakova, N. V., Mashkey, A. M., Petrov, R. V., Paliy, A. P., \& Ishchenko, K. V. (2018b). Contamination of animal-keeping premises with eggs of parasitic worms. Biosystems Diversity, 26 (4), 327-333. doi: 10.15421/011849

Paliy, A. P., Sumakova, N. V., Paliy, A. P., \& Ishchenko, K. V. (2018a). Biological control of house fly. Ukrainian Journal of Ecology, 8 (2), $230-234$. doi:10.15421/2018_332

Paliy, A. P., Zavgorodnii, A. I., Kalashnyk, M. V., Shkromada, O. I., Rybachuk, Z. V., ... Nedzheria, T. I. (2020a). Influence of new frost-resistant disinfectant on the ultrastructural organization of atypical mycobacteria. Ukrainian Journal of Ecology, 10 (3), 95-101. doi: 10.15421/2020_139

Paliy, A. P., Zavgorodniy, A. I., \& Bondarchuk, A. O. (2019a). Bactericidal properties of the "DOROSEPT SUPER" agent for mycobacteria. Bulletin of Poltava State Agrarian Academy, 4 (95), 159-165. doi: 10.31210/visnyk2019.04.20 (In Ukrainian)

Paliy, A. P., Zavgorodniy, A. I., Stegniy, B. T., \& Gerilovych, A. P. (2015). A study of the efficiency of modern domestic disinfectants in the system of TB control activities. Agricultural Science and Practice, 2 (2), 26-31. doi: 10.15407/agrisp2.02.026

Paliy, A. P., Zavgorodniy, A. I., Stegniy, B. T., \& Palii, A. P. (2020b). Scientific and methodological grounds for controlling the development and use of disinfectants. Monograph. Kharkiv. Miskdruk (in Ukrainian)

Paliy, A., Sumakova, N., Petrov, R., Shkromada, O., Ulko, L., \& Palii, A. (2019b). Contamination of urbanized territories with eggs of helmiths of animals. Biosystems Diversity, 27 (2), 118-124. doi: 10.15421/011916

Ponomarenko, G. V., Kovalenko, V. L., Ponomarenko, O. V., \& Balackiy, Yu. O. (2017a). Effects of microbicide based on lactic acid and metal nanoparticles on laboratory animals. Ukrainian Journal of Ecology, 7 (4), 482-485. doi: 10.15421/2017_148

Ponomarenko, G. V., Kovalenko, V. L., Ponomarenko, O. V., \& Balackiy Yu. O. (2017b). Research of the influence of disinfectants on the rate of absorption of oxygen by cells of Escherichia coli and Staphylococcus aureus bacteria. Journal for Veterinary Medicine, Biotechnology and Biosafety, 3 (4), 13-15.

Presgrave, R. de F., Camacho, L. A., \& Villas Boas, M. H. (2008). A profile of unintentional poisoning caused by household cleaning products, disinfectants and pesticides. Cadernos de Saúde Pública, 24 (12), 2901-2908. doi: 10.1590/S0102-311X2008001200019

Rabenau, H. F., Kampf, G., Cinatl, J., \&. Doerr, H. W. (2005). Efficacy of various disinfectants against SARS coronavirus. The Journal of Hospital Infection, 61 (2), 107-111. doi: 10.1016/j.jhin.2004.12.023

Rodionova, K. O., Paliy, A. P., Palii, A. P., Yatsenko, I. V., Fotina, T. I., ... Odyntsova, T. A. (2020). Effect of ultraviolet irradiation on beef carcass yield. Ukrainian Journal of Ecology, 10 (2), 410-415. doi: 10.15421/2020_118

Roeder, R. S., Lenz, J., Tarne, P., Gebel, J., Exner, M., \& Szewzyk, U. (2010). Long-term effects of disinfectants on the community composition of drinking water biofilms. International Journal of Hygiene and Environmental Health, 213 (3), 183-189. doi: 10.1016/j.ijheh.2010.04.007

Rutala, W. A. (1996). APIC guideline for selection and use of disinfectants. American Journal of Infection Control, 24 (4), $313-342$. doi: 10.1016/S0196-6553(96)90066-8

Shkromada, O., Skliar, O., Paliy, A., Ulko, L., Gerun, I., Naumenko, O., Ishchenko, K., Kysterna, O., Musiienko O., \& Paliy, A. (2019). Development of measures to improve milk quality and safety during production. Eastern-European Journal of enterprise technologies, 3/11 (99), 30-39. doi: $10.15587 / 1729-4061.2019 .168762$

Souza, A. L., Ceridório, L. F., Paula, G. F., Mattoso, L. H., \& Oliveira, O. N. Jr. (2015). Understanding the biocide action of poly(hexamethylene biguanide) using Langmuir monolayers of dipalmitoyl phosphatidylglycerol. Colloids Surf. B. Biointerfaces., 132, 117-121. doi: $10.1016 /$ j.colsurfb.2015.05.018

Stegniy, B. T., Paliy, A. P., Pavlichenko, O. V., Muzyka, D. V., Tkachenko, S. V., \& Usova, L. P. (2019). Virucidal properties of innovative disinfectant to Avian influenza virus and Newcastle disease virus. Journal for Veterinary Medicine, Biotechnology and Biosafety, 5 (3), 27-33. doi: 10.36016/JVMBBS-2019-5-3-6

Stringfellow, K., Anderson, P., Caldwell, D., Lee, J., Byrd, J., McReynolds, J., Carey, J., Nisbet, D., \& Farnell, M. (2009). Evaluation of disinfectants commonly used by the commercial poultry industry under simulated field conditions. Poultry science, 88 (6), 1151-1155. doi: 10.3382/ps.200800455

Susan, W., Wijnhoven, S., Peijnenburg, W., Herberts, C., Hagens, W., Oomen, A., Heugens, E., Roszek, B., Bisschops, J., Gosens, I., Van De Meent, D., Dekkers, S., De Jong, W., van Zijverden, M., Sips, A., \& Geertsma, R. (2009). Nano-silver - a review of available data and knowledge gaps in human and environmental risk assessment. Nanotoxicology, 3 (2), 2009, 109-138. doi: 10.1080/17435390902725914

akagi, G., \& Yagishita, K. (2020). Principles of Disinfectant Use and Safety Operation in Medical Facilities During Coronavirus Disease 2019 (COVID19) Outbreak. SN Compr. Clin. Med., 2, 1041-1044. doi: 10.1007/s42399-020-00413-x

Wason, S., Gomolin, I., Gross, P., Mariam, S., \& Lovejoy, F. H. Jr. (1984). Phosphorus trichloride toxicity. Preliminary report. The American journal of medicine, 77 (6), 1039-1042. doi: 10.1016/0002-9343(84)90185-2

Yousef, M. I., Abuzreda, A. A., \& Kamel, M. A. E.-N. (2019). Neurotoxicity and inflammation induced by individual and combined exposure to iron oxide nanoparticles and silver nanoparticles. Journal of Taibah University for Science, 13 (1), 570-578. doi:10.1080/16583655.2019.1602351.

Zavgorodniy, A. I., Paliy, A. P., Stegniy, B. T., \& Gorbatenko, S. K. (2019). Infrared milk pasterizer as a component of success in the animal leukemia control. Journal for Veterinary Medicine, Biotechnology and Biosafety, 5 (3), 5-9. doi: 10.36016/JVMBBS-2019-5-3-1

Zavgorodniy, A. I., Stegniy, B. T., Paliy, A. P., Gorjeev, V. M., \& Smirnov, A. M. (2013). Scientific and practical aspects of disinfection in veterinary medicine. Kharkiv: FOP Brovin O.V. (in Ukrainian) 


\section{Citation:}

Kovalenko, V.L., Ponomarenko, G.V., Kukhtyn, M.D., Paliy, A.P., Bodnar, O.O., Rebenko, H.I., Kozytska, T.G., Makarevich, T.V., Ponomarenko, O.V., Palii, A.P. (2020). Evaluation of acute toxicity of the "Orgasept" disinfectant.

Ukrainian Journal of Ecology, 10(4), 273-278.

(cc) $\mathrm{EY}$ This work is licensed under a Creative Commons Attribution 4.0. License 